\title{
PROSES KEPERAWATAN PADA AREA KEPERAWATAN GAWAT DARURAT
}

\author{
Syifahanun Septiani
}

Syifahanun.s@yahoo.co.id

\section{Latar belakang}

Proses keperawatan adalah aktivitas yang mempunyai maksud yaitu praktik keperawatan yang dilakukan dengan cara yang sistematik. Selama melaksanakan proses keperawatan, perawat menggunakan dasar pengetahuan yang komprehensif untuk mengkaji status kesehatan klien, membuat penilaian yang bijaksana dan mendiagnosa, mengidentifikasi hasil akhir kesehatan klien dan merencanakan, menerapkan dan mengevaluasi tindakan keperawatan yang tepat guna mencapai hasil akhir tersebut (Dermawan, 2012)

Proses keperawatan sebagai alat bagi perawat untuk melaksanakan asuhan keperawatan yang dilakukan pada pasien memiliki arti penting bagi kedua belah pihak yaitu perawat dan klien. Sebagai seorang perawat proses keperawatan dapat digunakan sebagai pedoman dalam pemecahan masalah klien, dapat menunjukkan profesi yang memiliki profesionalitas yang tinggi, serta dapat memberikan kebebasan kepada klien untuk mendapatkan pelayanan yang cukup sesuai dengan kebutuhannya.

Sehingga dapat dirasakan manfaatnya baik dari perawat maupun klien, manfaat tersebut antara lain dapat meningkatkan kemandirian pada perawat dalam melaksanakan tugasnya karena didalam proses keperawatan terdapat metode ilmiah keperawatan yang berupa langkah-langkah proses keperawatan, akan dapat meningkatkan kepercayaan diri perawat dalam melaksanakan tugas.

Karena klien akan merasakan kepuasan setelah dilakukan asuhan keperawatan dengan pendekatan proses keperawatan, akan dapat selalu meningkatkan kemampuan intelektual dan teknikal dalam tindakan keperawatan karena melalui proses keperawatan dituntut mampu memecahkan masalah yang baru sesuai dengan masalah yang dialami klien, sehingga akan timbul perasaan akan kepuasan kerja.

Dengan proses keperawatan, rasa tanggung jawab dan tanggung gugat bagi perawat itu dapat dimiliki dan dapat digunakan dalam tindakan-tindakan yang merugikan atau menghindari tindakan yang legal. Semua tatanan perawatan kesehatan secara hukum perlu mencatat observasi keperawatan, perawatan yang diberikan, dan respons pasien.Berfungsi sebagai alat komunikasi dan sumber untuk membantu dalam menentukan keefektifan perawatan dan untuk membantu menyusun prioritas keperawatan berkesinambungan. 


\section{Metode}

Artikel ilmiah ini dibuat dengan menggunakan metode literasi/membaca dan menganalisa kajian dari berbagai sumber/referensi terkait seperti jurnal, buku teks, dan e-book. Artikel ilmiah ini ditulis dengan mengacu pada sumber-sumber terkait yang berfokus pada proses keperawatan.

\section{Hasil}

Hasil analisa yang didapatkan adalah bahwa proses keperawatan yakni pusat atau inti dari tindakan keperawatan. Proses keperawatan adalah kunci untuk mengidentifikasi masalah keperawatan sehingga dapat mendukung kemampuan perawat untuk mengkaji status kesehatan klien melalui pendekatan untuk memecahkan masalah. Tujuannya tak lain adalah untuk meningkatkan asuhan keperawatan yang berkualitas dan tepat sasaran.

Sebelum menyusun suatu asuhan keperawatan yang baik, kita harus memahami langkah langkah dari proses keperawatan. Proses perawatan merupakan suatu metode bagi perawat untuk Memberikan asuihan keperawatan kepada klien. Beberapa pengertian proses kaparawatan adalah sebagai berikut Suatu metoda pemberian asuhan keperawatan yang sistematis dan rasional (Kozier, 1991).

Metoda pemberian asuhan keperawatan yang terorganisir dan sistematis, berfokus pada respon yang unik dari individu terhadap masalah kesehatan yang actual dan potensial (Rosalinda,1986). Suatu aktifitas yang dinamika dan berkelanjutan yang meliputi interaksi perawat klien dan proses pemecahan masalah (Schultz dan Videbeck).

Proses keperawatan bukan hanya sekedar pendekatan sistematik dan terorganisir melalui enam langkah dalam mengenali masalah-masalah klien, namun merupakan suatu metode pemecahan masalah baik secara episodic maupun secara linier. Kemudian dapat dirumuskan diagnosa keparawatannya, dan cara pemecahan masalah.

\section{Pembahasan}

Keperawatan gawat darurat bersifat cepat dan perlu tindakan yang tepat, serta memerlukan pemikiran kritis tingkat tinggi. Perawat gawat darurat harus mengkaji pasien meraka dengan cepat dan merencanakan intervensi sambil berkolaborasi dengan dokter gawat darurat. Dan 
harus mengimplementasikan rencana pengobatan, mengevaluasi evektivitas pengobatan, dan merevisi perencanaan dalam parameter waktu yang sangat sempit. Hal tersebut merupakan tantangan besar bagi perawat, yang juga harus membuat catatan perawatan yang akurat melalui pendokumentasian.

Di lingkungan gawat darurat, hidup dan mati seseorang ditentukan dalam hitungan menit. Sifat gawat darurat kasus memfokuskan kontribusi keperawatan pada hasil yang dicapai pasien, dan menekankan perlunya perawat mencatat kontribusi profesional mereka.

\section{A. Standar keperawatan}

Standar keperawatan merupakan tingkat pelaksanaan yang perawatnya memegang tanggung jawab, dan didefinisikan sebagai cara seorang perawat yang bijaksana akan memberikan perawatan lingkungan yang sama atau serupa. Pada tahun 1983, Emergency Nurses Association (ENA) membuat standar keperawatan untuk semua perawat profesional yang bekerja di lingkungan gawat darurat. Selanjutnya standar tersebut berfungsi sebagai rujukan untuk menentukan apakah kelalaian perawat gawat darurat menyebabkan atau berperan terhadap hasil pasien yang merugikan.

\section{B. Rekam Medik}

Catatan rekam medik memiliki 3 manfaat utama:

1. Rekam medis gawat darurat adalah catatan penting informasi pasien yang berguna untuk diagnosis dan pengobatan

2. Rekam medis digunakan untuk mempermudah pengantian biaya untuk institusi

3. Rekam medis merupakan catatan legal tentang pasien. Beberapa informasi mungkin saja diperlukan tidak dalam kaitannya dengan perjalan klinis, seperti untuk investigasi forensik yang melibatkan pernyataan korban, mekanisme cedera, pola luka dan sebagainya.

\section{Pentingnya Dokumentasi}

Melakukan dokumentasi secara akurat dalam rekam medis adalah salah satu cara terbaik bagi perawat klinis untuk membela diri dari tuntutan hukum karena kelalaian dalam pemberian perawatan. Pemahaman perawat dalam tanggung jawab profesionalnya yang dicapai dengan 
pembelajaran standar spesialis nasional, akan meningkatkan apresiasi mereka terhadap nilai dokumentasi sebagai alat pembuktian bahwa perawat telah memenuhi tugas-tugasnya terhadap pasien.

Pencatatan baik dengan computer, catatan naratif, atau lembar alur (FlowSheet) harus menunjukkan bahwa perawat gawat darurat telah melakukan pengkajian dan komunikasi, perancanaan dan kolaborasi, implementasi dan evaluasi perawatan yang diberikan. Serta melaporkan data-data penting kepada dokter selama situasi serius. Catatan tersebut harus menunjukkan bahwa perawat gawat darurat bertindak sebagai advokat pasien ketika terjadi penyimpangan standar perawatan yang mengancam keselamatan pasien.

Berikut adalah prinsip proses keperawatan pasien gawat darurat:

- Life support Perlu di prioritaskan kondisi yang memerlukan tindakan segera. Terkadang tindakan dilakukan bersamasaan dengan pengkajian. Penulisan dapat dilakukan setelah keselamatan terjamin atau sudah teratasi.

- Ringkas dan mudah dimengerti oleh karnanyaharus dibuat singkat dan jelas.

- Mayor kondisi dan holistik Diprioritaskan pada kondisi-kondisi utama yang mengganggu kehidupan atau kebutuhan dasar pasien dan keluarga dari segi fisik ,psiko dan sosial.

- Aktual atau benar Keakuratan dalam pengkajian dan perumusan diagnosa keperawatan dan tindakan keperawatan merupakan hal utama yang harus diingat.

Proses keperawatan pasien gawat darurat

\section{Pengkajian}

Berdasarkan pada sistem triage. Setelah primarisurve dan intervensi krisis selesai, perawat harus mengkaji riwayat diberikan oleh pasien adalah faktor kritikaldalam penentuan perawatan yang sesuai. Jika pasien tidak dapat meberikan informasi, keluarga atau teman bisa menjadi sumber data sekunder. AMPLE memonic dapat digunakan sebagai penggingat informasi komponen penting yang harus didata:

$\checkmark$ Allergie ( alergi )

$\checkmark$ medication ( pengobatan : termasuk frekuensi, dosis, dan rute ) 
$\checkmark$ Past medical histori ( riwayat medi, lalu seperti diabetes, masalah kardivaskuler atau pernapasan )

$\checkmark$ Oral inteks ( obat terakhir yang dikomsumsi )

$\checkmark$ Event s ( kejadian-kejadian ) keluhan utama, deskripsi gejala, mekanisme trauma.

Setelah primary surve dan riwayat pasien lengkap, surve umum, tanda-tanda vital dan pengkajian fisik head to toe harus dilakukan.

2. Analisa dan perencanaan Analisa yang tepat akan menunjang perumusan diagnosa keperawatan yang tepat serta intervensi sesuai protokol triage. Dibawah ini adalah masalah -masalah diagnosa keperawatan atau kolaborasi yang secara sering ditemukan pada pasien gawat darurat :

a) Tidak efektif nya bersihan jalan nafas berhubungan dengan opstruksi trakeo bronkial, sekret paru.

b) Kecemasan berhubungan dengan penyakit mengancam jiwa atau troma seperti amputasi, laserasi berat.

c) Tidak efktifnya pola napas berhubungan dengan troma dada, overdosis obat, gangguan neurologis.

d) Penurunan curah jantung penurunan aliran balik vena, gangguan jantung disebakan oleh listrik atau penyebab mekanik seperti tampona nadi jantung.

e) Tridak efektifnya koping individu berhubungan dengan amputasi tiba-tiba.

f) Keputusasaan berhubungan dengan troma tulang spinal menyebabkan paraplegia.

g) Nyeri berhubungan dengan troma, iskemia.

h) Ketidak berdayaan berhubungan dengan hilangnya kontrol ketika tes dianostik multiple.

i) Sindrom troma perkosaan berhubungan dengan penganiayaan seksual menyebabkan penghinaan, marah dan takut akan kehamilan

j) Perubahan perfusi jaringan berhubungan dengan interuksi aliran arteri dan vena disebabkan oleh trauma. 


\section{Evaluasi}

Yang dilakukan diruang gawat darurat meliputi evaluasi tentang pelaksanaan triage, keadaan dan status kesehatan pasien, dokumentasi dilakukan setiap tindakan selesai atau selama perawatan diunit gawat darurat dan evaluasi dengan cara sujebtif, objektif, analisa dan planning ( SOAP ).

\section{Penutup}

a. Kesimpulan

Istilah penatalaksanaaan kedaruratan secara tradisional mengacu pada perawatan yang diberikan pada pasien dengan kebutuhan urgen dan kritis dan tujuan utama penatalaksanaan medis kedaruratan adalah untuk mempertahankan hidup, mencegah keadaan memburuk sebelum penanganan pasti dapat diberikan, dan memulihkan pasien agar dapat hidup berguna. Peran perawat gawat darurat antara lain: Care giver/pemberi asuhan, client advocate, , collaborator, dan coordinator. Fungsi perawat adalah independen, dependen dan kolaborasi. Pemahaman terhadap aspek hukum dalam keperawatan gawat darurat bertujuan meningkatkan kualitas penanganan pasien dan menjamin keamanan serta keselamatan pasien.

b. Saran

Dalam kegiatan kegawatan daruratan sehari hari dan bencana peran perawat sangat signifikan oleh sebab itu pengembangan pengetahuan dan keterampilan keperawatan khususnya tentang gawat darurat dan bencana harus terus menerus dikembangkan, disisi lain tuntutan akan kepastian hukum legalitas perawat profesional juga harus ditempatkan secara proporsional dengan arti kata adanya keseimbangan antara hak dan kewajiban. 


\section{Daftar Pustaka}

1. Simamora, R. H. (2019). Development of Guidelines for Applying appropriate Patient Identification to Achieve Patient Safety Goal. INC2019 12th International Nursing Conference. 2019.10455 - 455 (1 pages) UCI(KEPA) : I410-ECN-0101-2019-512-001224337

2. Wilkinson, Judith M. 2007. Buku Saku DIAGNOSIS KEPERAWATAN dengan Intervensi NIC dan Kriteria Hasil NOC Edisi 7. Jakarta: EGC.

3. NANDA. (2018). Nursing Diagnoses: Definitions \& Classification 2018- 2020. Philadelphia: NANDA International.

4. Susiana, Endang. Wahyuni, E. D. \&Asmoro, C. P.(2019). Faktor Yang Berhubungan Dengan Mutu Pendokumentasian Asuhan Keperawatan. Fundamental And Management Nursing Journal. Vol. 2 No.1.

5. Nursalam. 2001. Proses dan Dokumentasi Keperawatan Konsep dan Praktik edisi 1. Jakarta : Salemba Medika

6. Lyer, Patricia W. 2004. Dokumentasi Keperawatan. Jakarta ; EGC.

7. Sadler, Marry kathryn, 1999, Proses Keperawatan, jakarta ; EGC

8. Triyoga, Hana. 2012. Asuhan Keperawatan Gawat Darurat Pada Ny. P Dengan Asma di IGD RSUD Sragen. Surakarta: Universitas Muhammadiyah Surakarta

9. Yudi, Yota. 2015. Gambaran Tingkat Kesadaran Perawat Dalam Melakukan Dokumentasi Keperawatan Gawat Darurat. Jakarta : Universitas Indonesia

10. Krisanty, p, et al. 2009. Ed. Asuhan Keperawatan Gawat Darurat. Jakarta : CV Trans Info Media, 103-105 
